\title{
UNSUR UNSUR DI PENGADILAN TATA USAHA NEGARA
}

\author{
Nama Mahasiswa : Suhargil \\ Email : suhargil90@gmail.com \\ No Bp : 1910003600337 \\ Perguruan Tinggi \\ Ilmu Hukum ( UNIVERSITAS EKA SAKTI PADANG )
}

\section{A.PENDAHULUAN}

Indonesia adalah Negara Hukum, sebagaimana ditegaskan dalam ketentuan Pasal 1 ayat (3) Undang-Undang Dasar Negara Republik Indonesia Tahun 1945 (UUD 1945). Sebagai negara hukum Indonesia menganut konsepsi welfare state (negara kesejahteraan), sebagaimana diisyaratkan dalam alinea keempat Pembukaan UUD 1945, yang merupakan tujuan negara. Dalam konsepsi welfare state, pemerintah diberi wewenang yang luas untuk campur tangan (staatsbemoeienis) di segala lapangan kehidupan masyarakat dalam rangka menyelenggarakan kesejahteraan umum (bestuurszorg). Campur tangan tersebut tertuang dalam ketentuan perundangundangan, baik dalam bentuk undang-undang, maupun peraturan pelaksanaan lainnya yang dilaksanakan oleh administrasi negara, selaku alat perlengkapan negara yang menyelenggarakan tugas servis publik. Negara hukum pada dasarnya terutama bertujuan untuk memberikan perlindungan hukum bagi rakyat. Perlindungan hukum bagi rakyat terhadap tindakan pemerintahan dilandasi oleh dua prinsip; prinsip hak asasi manusia dan prinsip negara hukum. Dalam negara hukum, setiap penyelenggaraan urusan pemerintahan haruslah

Berdasarkan pada aturan hukum yang berlaku (wetmatigheid van bestuur).Sebagai konsekuensi dari negara hukum, wajib adanya jaminan bagi administrasi negara sebagai alat perlengkapan negara untuk dapat menjalankan pemerintahan dan warga negara memiliki hak dan kewajiban mendapat jaminan perlindungan. Oleh karena itu, kekuasaan pemerintah tidak dapat lepas dari 
perkembangan asas legalitas yang telah dimulai sejak konsep negara hukum klasik formele rechtstaat atau liberale rechtsstaat yaitu wetmatigheid van bestuur artinya pemerintahan menurut undang-undang. Setiap tindakan pemerintah harus berdasarkan kepada undang-undang. Dalam melaksanakan fungsinya, aparat pemerintah mengadakan hubunganhubungan baik yang bersifat hubungan hukum maupun hubungan nyata dengan sesama aparat negara maupun dengan pihak perorangan baik yang berbentuk badan hukum maupun manusia pribadi (individu). Dalam menjalin hubungan hukum inilah terbentuk kegiatan-kegiatan atau aktivitas Pemerintah yang berunsurkan perbuatan-perbuatan aparat pemerintah. Dalam hukum administrasi yang penting adalah tindakan hukum, sebab suatu tindakan hukum akan menimbulkan akibat-akibat hukum tertentu bagi mereka yang terkena tindakan tersebut.Menurut ketentuan Undang-undang No. 5 tahun 1986, tindakan hukum yang dilakukan oleh badan/pejabat tata usaha negara yang dituangkan dalam suatu keputusan (beschikking), harus merupakan tindakan hukum dalam lapangan hukum tata usaha negara (hukum publik).10 6 Ridwan HR, 2013, Hukum Administrasi Negar

Tindakan hukum yang dilakukan oleh badan/pejabat tata usaha negara yang dituangkan dalam suatu keputusan tata usaha negara (beschikking) dapat diuji keabsahannya melalui gugatan di Pengadilan Tata Usaha Negara (PTUN) apabila diduga bertentangan dengan peraturan perundang-undangan dan/atau bertentangan dengan asas-asas umum pemerintahan yang baik (AAUPB). PTUN adalah salah satu pelaksana kekuasaan kehakiman bagi rakyat pencari keadilan terhadap sengketa tata usaha negara yang memiliki tugas dan wewenang untuk memeriksa, memutus dan menyelesaikan sengketa Tata Usaha Negara di tingkat pertama sebagaimana diamanatkan dalam Pasal 50 UndangUndang No. 5 tahun 1986 tentang Peradilan Tata Usaha Negara. Salah satu kewenangan PTUN yang paling penting selama proses pemeriksaan persidangan berlangsung adalah kewenangan untuk mengeluarkan suatu putusan (penetapan) sementara atau putusan sela atas keputusan pemerintah atau keputusan TUN yang sedang disengketakan. Begitu gugatan masuk dan didaftarkan di Kepaniteraan PTUN, pada saat itu juga PTUN dapat menghentikan keputusan pemerintah tersebut 
untuk tidak dilaksanakan, selama pemeriksaan proses perkara berlangsung. Putusan yang demikian disebut putusan penundaan, yang diatur di dalam Pasal 67 Undang-Undang No. 5 Tahun 1986.11

PTUN adalah salah satu pelaksana kekuasaan kehakiman bagi rakyat pencari keadilan terhadap sengketa tata usaha negara yang memiliki tugas dan wewenang untuk memeriksa, memutus dan menyelesaikan sengketa Tata Usaha Negara di tingkat pertama sebagaimana diamanatkan dalam Pasal 50 Undang-Undang No. 5 tahun 1986 tentang Peradilan Tata Usaha Negara. Salah satu kewenangan PTUN yang paling penting selama proses pemeriksaan persidangan berlangsung adalah kewenangan untuk mengeluarkan suatu putusan (penetapan) sementara atau putusan sela atas keputusan pemerintah atau keputusan TUN yang sedang disengketakan. Begitu gugatan masuk dan didaftarkan di Kepaniteraan PTUN, pada saat itu juga PTUN dapat menghentikan keputusan pemerintah tersebut untuk tidak dilaksanakan, selama pemeriksaan proses perkara berlangsung. Putusan yang demikian disebut putusan penundaan, yang diatur di dalam Pasal 67 Undang-Undang No. 5 Tahun 1986.11 


\section{B .PEBAHASAN}

UU PERATUN, UU 51/2009,Psl. 1 angka 9 . Keputusan Tata Usaha Negara adalah suatu penetapan tertulis yang dikeluarkan oleh badan atau pejabat tata usaha negara yang berisi tindakan hukum tata usaha negara yang berdasarkan peraturan perundangundangan yang berlaku, yang bersifat konkret, individual, dan final, yang menimbulkan akibat hukum bagi seseorang atau badan hukum perdata

Unsur unsur;

1.Penetapan tertulis

2.dikeluarkan oleh badan atau pejabat tata usaha negara

3.berisi tindakan hukum tata usaha negara

4.berdasarkan peraturan perundangundangan yang berlaku

5.bersifat konkret, individual, dan final

6.menimbulkan akibat hukum bagi seseorang atau badan hukum perdata

\section{PENJELASAN penetapan tertulis}

- UU 51/2009 CUKUP JELAS

- UU 5/1986 menunjuk kepada isi dan bukan kepada bentuk. ( tidak mesti formal SURAT KEPUTUSAN )

- Persyaratan tertulis itu diharuskan untuk kemudahan segi pembuktian. • sebuah memo atau nota dapat memenuhi syarat tertulis apabila sudah jelas

- a. Badan atau Pejabat Tata Usaha Negara mana yang mengeluarkannya;

- b. maksud serta mengenai hal apa isi tulisan itu;

- c. kepada siapa tulisan itu ditujukan dan

- D. apa yang ditetapkan di dalamnya 


\section{BADAN ATAU PEJABAT TATA USAHA NEGARA}

- PENJELASAN UU 5/1986 Badan atau Pejabat di pusat dan daerah yang melakukan kegiatan yang bersifat eksekutif.

- PASAL 1 angka 8 UU 51/2009 Badan atau Pejabat Tata Usaha Negara adalah badan atau pejabat yang melaksanakan urusan pemerintahan berdasarkan peraturan perundang-undangan yang berlaku.

\section{TINDAKAN HUKUM TATA USAHA NEGARA}

-UU 51/2009.PSL 1 angka 7 Tata Usaha Negara adalah administrasi negara yang melaksanakan fungsi untuk menyelenggarakan urusan pemerintahan baik di pusat maupun di daerah.

- PENJELASAN UU 5/1986 perbuatan hukum Badan atau Pejabat Tata Usaha Negara yang bersumber pada suatu ketentuan hukum Tata Usaha Negara yang dapat menimbulkan hak atau kewajiban pada orang lain.

\section{BERDASARKAN PERATURAN PERUNDANG-UNDANGAN YANG BERLAKU}

- PENJELASAN CUKUP JELAS

-PERATURAN PERUNDANG-UNDANGAN • UU 12/2011 peraturan tertulis yang memuat norma hukum yang mengikat secara umum dan dibentuk atau ditetapkan oleh lembaga negara atau pejabat yang berwenang melalui prosedur yang ditetapkan dalam Peraturan Perundangundangan BAB III JENIS, HIERARKI, DAN MATERI MUATAN PERATURAN

\section{PERUNDANGUNDANGAN BERSIFAT KONKRET, INDIVIDUAL, DAN FINAL}

- PENJELASAN UU 5/1986

- Bersifat konkret, artinya tidak abstrak, tetapi berwujud, tertentu atau dapat ditentukan

- Bersifat individual artinya tidak ditujukan untuk umum, tetapi tertentu baik alamat maupun hal yang dituju. Kalau yang dituju itu lebih dari seorang, tiap-tiap nama orang yang terkena keputusan itu disebutkan. 
- Bersifat final artinya sudah definitif dan karenanya dapat menimbulkan akibat hukum. Keputusan yang masih memerlukan persetujuan instansi atasan atau instansi lain belum bersifat final karenanya belum dapat menimbulkan suatu hak atau kewajiban pada pihak yang bersangkutan. menimbulkan akibat hukum bagi seseorang atau badan hukum perdata

- menimbulkan suatu hak atau kewajiban pada pihak yang bersangkutan.

\section{- MERUBAH MENGHILANGKAN KERUGIAN HAK GUGAT UU ADMINISTRASI}

- Pasal 87 Dengan berlakunya UndangUndang ini, Keputusan Tata Usaha Negara sebagaimana dimaksud dalam UndangUndang Nomor 5 Tahun 1986 tentang Peradilan Tata Usaha Negara sebagaimana telah diubah dengan Undang-Undang Nomor 9 Tahun 2004 dan UndangUndang Nomor 51 Tahun 2009 harus dimaknai sebagai: UNSUR-UNSUR

- a. penetapan tertulis yang juga mencakup tindakan faktual

- b. Keputusan Badan dan/atau Pejabat Tata Usaha Negara di lingkungan eksekutif, legislatif, yudikatif, dan penyelenggara negara lainnya

- c. berdasarkan ketentuan perundang-undangan dan AUPB

- d. bersifat final dalam arti lebih luas;

- e. Keputusan yang berpotensi menimbulkan akibat hukum; dan/atau

- f. Keputusan yang berlaku bagi Warga Masyarakat. PERLUASAN

- penetapan tertulis (tindakan faktual - TINDAKAN FAKTUAL • PASAL 1 ANGKA 8 ( Tindakan Administrasi Pemerintahan yang selanjutnya disebut Tindakan adalah perbuatan Pejabat Pemerintahan atau penyelenggara negara lainnya untuk melakukan dan/atau tidak melakukan perbuatan konkret dalam rangka penyelenggaraan pemerintahan

- di lingkungan legislatif, yudikatif, dan penyelenggara negara lainnya

- PSL 1 ANGKA 3 ( Badan dan/atau Pejabat Pemerintahan adalah unsur yang melaksanakan Fungsi pemerintahan, baik di lingkungan pemerintah maupun penyelenggara negara lainnya 
- PSL 1 ANGKA 2 ( Fungsi Pemerintahan adalah fungsi dalam melaksanakan Administrasi Pemerintahan yang meliputi fungsi pengaturan, pelayanan, pembangunan, pemberdayaan, dan pelindungan.

- Penyelenggara Negara (Pasal 1 angka 1 UU No. 28 Tahun 1999 tentang Penyelenggara Negara yang Bersih dan Bebas dari Korupsi, Kolusi, dan Nepotisme (“UU 28/1999”), yang menyatakan sebagai berikut:

- Penyelenggara Negara adalah Pejabat Negara yang menjalankan fungsi eksekutif, legislatif, atau yudikatif dan pejabat lain yang fungsi dan tugas pokoknya berkaitan dengan penyelenggaraan negara sesuai dengan ketentuan peraturan perundang- undangan yang berlaku.

- Kemudian, di dalam Pasal 2 UU 28/1999 dijelaskan siapa saja yang termasuk penyelenggara negara, yaitu

1. Pejabat Negara pada Lembaga Tertinggi Negara;

2. Pejabat Negara pada Lembaga Tinggi Negara;

3. Menteri

4. Gubernur;

5. Hakim;

6. Pejabat negara yang lain sesuai dengan ketentuan peraturan perundang- undangan yang berlaku; dan

7. Pejabat lain yang memiliki fungsi strategis dalam kaitannya dengan penyelenggara negara sesuai dengan ketentuan peraturan perundang-undangan yang berlaku. $\bullet$. berdasarkan ketentuan perundang-undangan dan AUPB

- PSL 1 ANGKA 17 prinsip yang digunakan sebagai acuan penggunaan Wewenang bagi Pejabat Pemerintahan dalam mengeluarkan Keputusan dan/atau Tindakan dalam penyelenggaraan pemerintahan. 
- Pasal 10 • (1) AUPB yang dimaksud dalam Undang-Undang ini meliputi asas: a. kepastian hukum; b. kemanfaatan; c. ketidakberpihakan; d. kecermatan; e. tidak menyalahgunakan kewenangan; f. keterbukaan; g. kepentingan umum; dan h. pelayanan yang baik.

- bersifat final dalam arti lebih luas

- PENJELASAN Yang dimaksud dengan "final dalam arti luas" mencakup Keputusan yang diambil alih oleh Atasan Pejabat yang berwenang.

- . Keputusan yang berpotensi menimbulkan akibat hukum

- Rancangan , Rencana, disposisi...

- Keputusan yang berlaku bagi Warga Masyarakat.

- PASAL 1 ANGKA 15 Warga Masyarakat adalah seseorang atau badan hukum perdata yang terkait dengan Keputusan dan/atau Tindakan. Keputusan administrasi pemerintahan

- Ps1 1 angka. disebut Keputusan Tata Usaha Negara atau Keputusan Administrasi Negara yang selanjutnya disebut Keputusan adalah ketetapan tertulis yang dikeluarkan oleh Badan dan/atau Pejabat Pemerintahan dalam penyelenggaraan pemerintahan. Unsur ketetapan tertulis dikeluarkan oleh Badan dan/atau Pejabat Pemerintahan • dalam penyelenggaraan pemerintahan Perbandingan;

\section{C.PENUTUP}

Fungsi PTUN dalam memberikan perlindungan terhadap kelestarian lingkungan adalah belum optimal. putusan-putusan pengadilan TUN yang obyek sengketanya dibidang lingkungan hidup belum memberikan perlindungan kelestarian secara optimal, karena hakim cenderung bersifat prosedural formalistik dalam menggunakan pertimbangannya, dan kurang menyentuh subtansi atau pokok perkaranya terkait dengan lingkungan hidup dan kelestariannya. Dalam 
beberapa putusan pengadilan TUN yang obyek sengketanya sama yaitu mengenai kelayakan atau ketidaklayakan lingkungan diputus secara bertentangan dan lebih memihak kepada pemilik modal besar dari pada memberikan perlindungan terhadap kelestarian hutan. belum optimalnya fungsi PTUN disebabkan adanya kendala-kendala yang meliputi kendala terhadap peraturan perundang-undangan, kendala terhadap asas-asas huikum,dan kendala terhadap pelaksana hukum.

Pengadilan Tata Usaha Negara mempunyai tugas dan wewenang:"memeriksa, memutus dan menyelesaikan sengketa tata usaha negara, yaitu suatu sengketa yang timbul dalam bidang hukum TUN antara orang atau badan hukum perdata (anggota masyarakat) dengan badan atau pejabat TUN (pemerintah) baik dipusat maupun didaerah sebagai akibat dikeluarkannya suatu keputusan TUN ,termasuk sengketa kepegawaian berdasarkan peraturan perundang-undangan yg berlaku (vide pasal 50 jo. pasal 1 angka 4 undang-undang nomor 5 tahun 1986 juncto undangundang nomor 9 tahun 2004 juncto undang-undang nomor 51 tahun 2009)".

Sarat untuk mengatasi belum optimalnya fungsi PTUN adalah melakukan penyempurnbaan peraturan perundang-undangan ; memesukkan asas pem bangunan berkelanjutan dan asas pencegahan dini sebagai dasar pengujian KTUN obyek sengketa dalam pen yelesaian sengketa di PTUN; segera dibentuk pengadilan TUN di tiap kabupaten/kota dan pengadilan tinggi TUN di tiap provinsi; memberikan sanksi yang dapat dipaksakan kepada para pejabat yg tidak melaksanakan putusan PTUN; 
dibentuk pengadilan kusus lingkungan di bawah peradilan tata usaha negara yg diharapkan mampu memeriksa dan menmgadili sengketa secara mendalam dari aspek subtansi.

\section{DAFTAR PUSTAKA}

Pasal 1 ayat (3) Undang-Undang Dasar Negara Republik Indonesia Tahun 1945

Supandi, 2011, Hukum Peradilan Tata Usaha Negara (Kepatuhan Hukum Pejabat Dalam Mentaati Putusan Pengadilan Tata Usaha Negara), Pustaka Bangsa Press, Medan,

Sjachran Basah, 2010, Eksistensi dan Tolok Ukur Badan Peradilan Administrasi Negara Republik Indonesia, Alumni, Bandung, hlm. 192-193.

Zairin Harahap, 2002, Hukum Acara Peradilan Tata Usaha Negara, Edisi Revisi, Rajawali Pers, Jakarta,

Philipus M. Hadjon, 1987, Perlindungan Hukum Bagi Rakyat di Indonesia, PT Bina IImu, Surabaya, hlm. 71

Ridwan HR, 2013, Hukum Administrasi Negara, Edisi Revisi, Rajawali Pers, Jakarta, hlm. 17

Irfan Fachruddin, 2004, Pengawasan Peradilan Administrasi Terhadap Tindakan Pemerintah, PT. Alumni Bandung, hlm. 43-44.

Muchsan, 1981, Beberapa Catatan Tentang Hukum Administrasi Negara dan Peradilan Administrasi Negara di Indonesia, Liberty, Yogyakarta, hlm. 17.

Marbun, 1997, Peradilan Administrasi Negara dan Upaya Administrasi di Indonesia, Liberty, Yogyakarta, hlm. 146. 